\title{
Self-employment and marriage: costs and benefits
}

\author{
Cathy M. Haselau \& Madhubala I. Kasiram* \\ Department of Social Work, University of Durban-Westville, Private Bag X54001, Durban, 4000 Republic of South Africa
}

Received February 1996

\begin{abstract}
This article highlights the effect of self-employment in a marriage by examining both the costs and possible benefits that are brought to bear when the breadwinner is in self-employment. Specific aspects identified as having an impact on the marital relationship were: work-family conflicts; role-division; stress; motivation for the start up of the business; the structure of the business; financial management; and personality characteristics. Via the interview schedule, it was possible to glean in-depth information from both spouses in the marriage on the advantages and disadvantages of being selfemployed. Finally, recommendations are made both for therapeutic and preventive interventions with the couple as well as for interdisciplinary communication.
\end{abstract}

\begin{abstract}
Hierdie artikel werp lig op die effek wat selfwerksaamheid op 'n huwelik kan hê. Beide die onkoste en moontlike voordele vir die huwelik wanneer die broodwinner vir hom/haarself werk, word ondersoek. Spesifieke aspekte is geidentifiseer wat 'n groot uitwerking op die huweliksverhouding uitoefen. Hierdie aspekte is: werk-gesin-konflikte; rolverdeling; stres; motivering om met die besigheid te begin; die struktuur van die sake-onderneming; finansiële bestuur; en persoonlikheidseienskappe. As gevolg van die onderhoudskedule was dit moontlik om intensiewe inligting van albei eggenote oor die voordele en nadele van selfwerksaamheid in te samel. Ten slotte word aanbevelings gemaak ten opsigte van terapeutiese en vonrsorgmaatreëls vir die egpaar, sowel as vir interdissiplinêre kommunikasie.
\end{abstract}

*Author to whom correspondence should be addressed.

\section{Problem definition}

The South African economy has been in recession for several years. The rough passage of political change, a 'demand' mentality amongst employees and unabated violence have detrimentally affected investor confidence. Yet in the Annual Report of the Small Business Development Corporation Limited (SBDC, 1993: 8), local small and medium business sectors have been reported to provide job opportunities which the large business sector cannot. This trend finds support in statistics provided by the World Bank which indicate that only $8.4 \%$ of the 400000 South Africans who enter the work force annually, will find formal employment. The remaining 91.6\% will have to create their own employment opportunities (Small Business Week, 4-11 September, 1993: 4). Thus the small and medium business sectors are set to become significantly more important role players in the upliftment of the South African economy. This is in accord with the principles of participation and involvement of the micro system, in the Reconstruction and Development Programme. to promote a philosophy of empowerment of all 'service users and their families' in South Africa (Taylor, 1994).

Despite the importance of small business, South African research has focussed mainly on business management aspects or demographic aspects of the self-employed (Snyman, 1991). Research on social effects of self-employment has been largely neglected. A holistic perspective of the individual has been sacrificed to specialist knowledge.

In order to perceive the self-employed individual holistically, it is necessary to view him systemically at a micro level as an individual, as part of the family system; as well as at a macro level, as part of the social and employment system. All these levels function interdependently, with each being more than the sum of its parts, and change in one resulting in change in the others. Individuals and their family relationships are always changing due to biological development and external influences; yet as the individual and family changes, so the social context adapts in response. Relationships within and outside of the family are always evolving and are seen as recursive, circular and reciprocal (Tomm, 1984). This study is focussed on the interactions between the individual, marriage, the family and employment.

Pottick (1989), in a study conducted in America, examined the relationship between work and other aspects of living, such as family life. She found that there were differing degrees of satisfaction to work by persons in various occupations, with labourers and clerical workers expressing the lowest levels of satisfaction compared with farmers, professionals and managers. Since work occupies the bulk of one's waking time, it is expected that work satisfaction would affect one's overall sense of well being and consequently affect one's married life as well. Although the present study does not focus on the differences in levels of satisfaction amongst different workers, it highlights the impact of the work sub system on marriage.

Specific aspects have been identified as having an impact on marriage. A significant contributor to stress in the marriage is work-family conflict, being defined as

'a form of interrole conflict in which the role pressures from the work and family domains are mutually incompatible in some respects' (Duxbury \& Higgins, 1991: 61).

Beutell \& Greenhaus (1983) highlighted the significance of role-division conflicts as a contributor to stress in marriage when the woman is in employment. They point out that trying to meet all role expectations through time management was ineffective and produced great stress. Cooper \& Davidson (1987) identified two main stressors apart from work, these being home environment and social environment stresses. These impact on family and marital life. Social stresses pertinent to South Africans described by these authors, are the risk of anomie or normlessness and alienation which is especially great in a time of political and social upheaval and economic constraint where one relocates to a new and foreign surrounding to secure some form of employment and income. These 
stresses apply to the majority of the country's citizens, evidence of which reach us daily through the mass media if not personal experience.

Business aspects that impact on the marriage are the motivation for starting up the business, the structure of the business and financial management. Snyman (1991) found that a variety of resources were utilized as initial capital for the business such as rotating credit societies, formal bank loans and the SBDC. Without sound management of the finances, the risks and responsibilities for repaying borrowed monies can become heavy burdens for any entrepreneur. In South Africa, with escalating levels of violence and crime along with a decline in foreign investor confidence, new and innovative ways have to be found to ensure the survival of the self-employed. Personality characteristics of this vulnerable group of persons have to include self-confidence, ability to face adversity, high achievement drive, superior conceptual ability to see through confusion and being willing and able to take risks (Olm \& Eddy, 1985). Survival of both the business and the marriage could well receive a helping hand through research to identify what are the costs and benefits to the marriage when the breadwinner is in self-employment since both have a reciprocal relationship on one another. This forms the field of study in this report.

\section{Research methodology}

The phenomenological philosophy of social science research in which the humanist approach is emphasized (Mouton, 1989), was used in this study. The individual within this approach is understood in terms of the meanings he/she ascribes to reality. This philosophy includes the subject's perceptions and there is engagement and empathy between subject and researcher. The individual reacts within his/her social structure in accord with meanings ascribed by him/her to that environment, and therefore these meanings need to be taken into account and understood. As this study explored new relationships between owning one's own business and marriage, it was important to take cognisance of the meaning ascribed to both these sub systems together with their interactive relationships on one another. The methodologies employed in this study were consistent with the phenomenological philosophy and entailed participant observation and interviewing, life history methods and qualitative content analyses.

The paucity of literature on the interactive relationship between marriage and owning one's own business rendered the study essentially exploratory, deeming it necessary that qualitative data become available on the topic. As Tripodi, Fellin \& Meyer (1993: 37) indicate, the purpose of exploratory research is to develop ideas and hypotheses especially where there is a paucity of information. Deshpande (1983) too asserts that when the humanist approach to research is used, qualitative methods are preferred. The subject's frame of reference is used to understand behaviour. Measurement is 'naturalistic, uncontrolled and observational' (Deshpande, 1983: 103). To this end, the interview schedule was used to yield rich qualitative data from a small select sample. Tripodi (1983: 75) indicates that valid, verifiable data is obtainable through careful probing when using the interview schedule. Indeed, probing was a concomitant part of the fieldwork phase as respondents had not taken time to consider the effect of self-employment on their marriages.

\section{Sample}

Taking into consideration the disadvantages of using the interview schedule as proposed by Tripodi (1983) and Bailey (1978), it was evident that the cost of interviewing many respondents from a wide geographical location would have been too high, necessitating geographical restrictions to the greater Durban area and a manageable sample size. Another disadvantage was that respondents could not remember events being queried without time consuming probing, rendering it feasible to utilize a small select sample with whom the researcher could spend sufficient time for yielding meaningful qualitative data.

Moon, Dillon \& Sprenkle (1990: 360) indicate that nonprobability samples are used in exploratory research. In this study, availability sampling as one category of non-probability sampling was used. The researcher was employed at the counselling agency from whence the sample was derived. Men who were self-employed and their wives who had both received counselling from the Family and Marriage Society of Durban (hereafter referred to as FAMSA) between 1 April 1991 to 31 March 1993 were contacted by letter. All those couples who responded were interviewed separately by appointment by the researcher. Altogether 24 interviews, representing 12 marriages, were conducted with husbands and wives.

Within the phenomenological philosophical framework, the systemic paradigm provided the theoretical grounding for exploring the interactive relationship between self-employment and marriage. The research tool was pilot tested and refined before final use in the study. Questions focussed on motivation and feelings about self-employment, potential workhome conflicts, role-division, time management, parenting and the use of leisure time. Stress was explored in detail, discussing the stressors both at work and at home, as well as the coping methods used.

\section{Limitations of the study}

Some of the limitations in this study included:

- The small sample size which limits the generalizability of the results. However, as this study was essentially exploratory, the degree of generalization did not invalidate the findings of the study.

- Only spouses who had counselling at FAMSA were approached, which biases the sample.

- The interviews were all done in the early evening straight after work, when families require private time and when tiredness could have affected both the interviewer and the couple. This was obviated by appointments being made to suit respondents and by the interviewer being skilled in both couple and family therapy.

\section{Results}

Altogether 24 separate interviews were conducted with husbands and wives. Application of the Pearson Chi-square test revealed that there were no significant differences when comparing responses of husbands and wives except with regard to the following: 
Table 1 Identifying details

\begin{tabular}{|c|c|c|c|c|c|c|c|c|c|c|c|c|}
\hline & $\begin{array}{l}\text { Age of } \\
\text { husband }\end{array}$ & $\begin{array}{l}\text { Age of } \\
\text { wife }\end{array}$ & $\begin{array}{l}\text { No. of } \\
\text { children }\end{array}$ & $\begin{array}{l}\text { Ages of } \\
\text { children }\end{array}$ & $\begin{array}{l}\text { Family } \\
\text { structure }\end{array}$ & $\begin{array}{l}\text { Education } \\
\text { husband }\end{array}$ & $\begin{array}{l}\text { Education } \\
\text { wife }\end{array}$ & $\begin{array}{l}\text { Work } \\
\text { husband }\end{array}$ & $\begin{array}{l}\text { Work } \\
\text { wife }\end{array}$ & $\begin{array}{l}\text { Salary } \\
\text { husband }\end{array}$ & $\begin{array}{l}\text { Salary } \\
\text { wife }\end{array}$ & $\begin{array}{l}\text { Management } \\
\text { courses }\end{array}$ \\
\hline 1. & 37 & 41 & 3 & $\begin{array}{l}14 \\
16 \\
5\end{array}$ & Extended & $\begin{array}{l}\text { Sid } 9 \\
\text { Trade }\end{array}$ & $\begin{array}{l}\text { Matric } \\
\text { Typing } \\
\text { course }\end{array}$ & Construction & Receptionist & R 2000 & - & - \\
\hline 2. & 60 & 58 & 3 & $\begin{array}{l}32 \\
29 \\
27\end{array}$ & $\begin{array}{l}\text { Nuclear } \\
\text { (couple) }\end{array}$ & Std 8 & $\begin{array}{l}\text { Matric } \\
2 \text { years } \\
\text { university }\end{array}$ & Hotelier & $\begin{array}{l}\text { House- } \\
\text { wife }\end{array}$ & R 6000 & $\mathbf{R} 800$ & $\begin{array}{l}\text { Management } \\
\text { course }\end{array}$ \\
\hline 3. & 42 & 36 & 2 & $\begin{array}{l}11 \\
9\end{array}$ & Nuclear & Std 8 & Matric & $\begin{array}{l}\text { Owns super- } \\
\text { market }\end{array}$ & $\begin{array}{l}\text { House- } \\
\text { wife }\end{array}$ & R3000 & - & - \\
\hline 4. & 40 & 37 & 2 & $\begin{array}{l}12 \\
8\end{array}$ & Nuclear & Std 9 & Std 6 & $\begin{array}{l}\text { Owns } \\
\text { canteen }\end{array}$ & $\begin{array}{l}\text { House- } \\
\text { wife }\end{array}$ & R3 000 & - & - \\
\hline 5. & 38 & 35 & 2 & $\begin{array}{l}10 \\
8\end{array}$ & Nuclear & $\begin{array}{l}\text { Std } 8 \\
\text { Trade }\end{array}$ & $\begin{array}{l}\text { Journalist } \\
\text { diploma }\end{array}$ & $\begin{array}{l}\text { Con- } \\
\text { struction }\end{array}$ & $\begin{array}{l}\text { Real } \\
\text { estate }\end{array}$ & R5 000 & & - \\
\hline 6. & 37 & 33 & 2 & $\begin{array}{l}11 \\
7\end{array}$ & Nuclear & Matric & BA & $\begin{array}{l}\text { Fire } \\
\text { protection }\end{array}$ & $\begin{array}{l}\text { Real } \\
\text { estate }\end{array}$ & R4000 & & $\begin{array}{l}\text { SBDC } \\
\text { course }\end{array}$ \\
\hline 7. & 40 & 36 & 2 & $\begin{array}{l}9 \\
6\end{array}$ & Nuclear & Matric & Matric & Advertising & $\begin{array}{l}\text { Merchand- } \\
\text { ising }\end{array}$ & R3 000 & R2 000 & $\begin{array}{l}\text { Management } \\
\text { diploma }\end{array}$ \\
\hline 8. & 45 & 40 & 4 & $\begin{array}{l}12 \\
10 \\
8 \\
4\end{array}$ & Nuclear & Degree & Degree & Dentist & Secretary & $\mathrm{R} 12000$ & R1 500 & $\begin{array}{l}\text { Management } \\
\text { courses }\end{array}$ \\
\hline 9. & 50 & 47 & $3(1+2)$ & $\begin{array}{l}22 \\
19 \\
19\end{array}$ & $\begin{array}{l}\text { Step } \\
\text { family }\end{array}$ & B.Sc & $\begin{array}{l}\text { Secretay } \\
\text { diploma }\end{array}$ & Accountant & Secretary & $\mathrm{R} 12000$ & R4 000 & - \\
\hline 10 & .36 & 36 & 2 & $\begin{array}{l}11 \\
8\end{array}$ & Nuclear & Diploma & Diploma & $\begin{array}{l}\text { Auto- } \\
\text { electrician }\end{array}$ & Teacher & R2 000 & R2 000 & - \\
\hline 11 & .24 & 21 & - & - & $\begin{array}{l}\text { Nuclear } \\
\text { (couple) }\end{array}$ & Matric & Matric & $\begin{array}{l}\text { Owns } \\
\text { shop }\end{array}$ & $\begin{array}{l}\text { House- } \\
\text { wife }\end{array}$ & - & - & - \\
\hline 12 & & 33 & - & - & $\begin{array}{l}\text { Nuclear } \\
\text { (couple) }\end{array}$ & Diploma & Degree & $\begin{array}{l}\text { Computer } \\
\text { tec }\end{array}$ & $\begin{array}{l}\text { Nursing } \\
\text { sister }\end{array}$ & R2 000 & R3200 & - \\
\hline
\end{tabular}

1. husbands' and wives' feelings about the husband's responsibility and commitment to the business, where the value was 13.631 , with two degrees of freedom, and a probability score of 0.001 . This means that these differences are significant at the $95 \%$ level;

2. whether home interfered more with work, or work interfered more with home, where the value was 6.471 , with two degrees of freedom and a probability level of 0.039 . This means that these differences were significant at the 95\% level.

These differences in the spouses' response could be attributed to poor communication and differing perceptions between spouses, pointing to a need for therapeutic intervention to bridge the communication gap.

Costs and benefits of self-employment in a marriage are reflected in four main advantages and four main disadvantages that emerged from the study.

\section{Advantages}

\section{Financial benefits}

The financial benefit of being self-employed was seen as the strongest motivating factor to starting the business by $37 \%$ of the husbands. In spite of extrinsic influences such as the present political/economic climate impacting on their businesses, as perceived by $54 \%$ of the businessmen in this study, the financial benefits of being self-employed were still viewed as a primary benefit. Also mentioned as a benefit was having a steady income through self-employment, thereby maintaining economic independence despite job reservation policies which had resulted in unemployment or low salaries. A further financial benefit mentioned was living where one wanted to, without incurring unnecessary relocation costs when new jobs are obtained.

One of the clearly expressed concerns in the light of economic independence was not being paid for the value and quality of work especially amongst respondents who had good qualifications, leading to job dissatisfaction. This finding contrasts with those of Pottick (1989) wherein work satisfaction increased in accord with the qualification and status of the position. This difference may be explained by the peculiar situation faced by South Africans today where having a secure job may be considered a benefit in itself because of the problem of high levels of unemployment in the country. 


\section{Increase in self-esteem of husbands}

Both husbands (75\%) and wives (83\%) noted an increase in self-esteem in the husband, and attributed this directly to the husband being self-employed. Comments such as 'It feels good and satisfying', were made. Altogether 29\% of the wives commented that one of the advantages of being selfemployed for them was that their husbands were happy. It was noteworthy that only the two men who experienced previous business collapse, had poor self-images with regard to the business. This finding is consistent with the conclusions reached by Welch in Olm \& Eddy (1985) wherein personality characteristics of the self-employed included having the driving force to make things work in the face of adversity.

\section{Increase in status and recognition from community}

Community recognition as an advantage of self-employment was mentioned by $43 \%$ of husbands. When comparing the pleasure in recognition with the personality characteristics of the husbands, half of them had a relatively high need for status, while $91 \%$ of the husbands had a very high need for achievement. These findings concur with those of Welch in Olm \& Eddy (1985:3) where a 'high degree of achievement orientation' is mentioned amongst the attributes to be possessed by the self-employed.

\section{Appreciation of spouse's parenting}

Husbands appreciated the parenting role performed by their wives, acknowledging that they were not always able to adequately fulfil this role because of limited time. When they did have time to parent, they enjoyed it. This finding is in congruence with those of Duxbury \& Higgins (1991) who concluded from their findings of work-family conflict that a redistribution of roles to match increased role responsibilities within the family has not yet occurred. The findings however contradict those of Baruch \& Barnett (1986) where greater participation in parenting resulted in fathers feeling more competent in parenting, but without any increase in satisfaction in parenting or appreciation of parenting functions performed by their spouses.

\section{Disadvantages}

\section{Financial insecurity}

This was viewed as one of the more stressful elements of selfemployment and finds support in the findings of Cooper \& Davidson (1987) which classify stressors as environmental or social. A restricted economic climate may be viewed as a source of environmental stress. Respondents in the study were acutely aware of the need for sufficient work to cover overheads such as salaries, pension and medical aid contributions, rent, lights, water, etc. While husbands expressed concern with covering overhead costs, wives tended to mention problems such as not having a medical aid or a pension. Both husbands and wives feared that unless responsible partners or managers assisted in the business, no gains would be forthcoming.

\section{Responsibility}

Bearing financial responsibility for the business was found to be very stressful. This disadvantage is inextricably linked to the concern regarding financial insecurity. Both husbands and wives in this study were preoccupied with sufficient work coming in and marketing the business if this was not happening. Even when this was not a problem, the responsibility of maintaining quality was regarded as stressful, creating a constant state of tension to strive for excellence and survival in the business. It is this drive for confronting and surviving adversities that Welch (Olm \& Eddy, 1985) refers to as an essential prerequisite for the self-employed businessman, which will contribute to the success of the business and accordingly reduce the risk of tensions in the marriage. Altogether $75 \%$ of the husbands felt positively about the extra responsibility in self-employment (perhaps because of possessing the essential characteristics), but $75 \%$ of their wives felt negatively about it, and this difference was statistically significant, as mentioned previously. The finding that wives involved in the business were discontented is commensurate with the finding by Beutell \& Greenhaus (1983) where employed women experienced great stress when attempting to manage their time in such a way that they 'coped' with all roles.

\section{Stress and moodiness as a result of responsibility}

The emotional strain of the responsibility of the business on the husband was of concern to $27 \%$ of the wives in this study. The concern was for both the husband himself - his physical and emotional health - as well as for the resulting tensions in the home. The wives saw work therefore interfering more with the home life, while their husbands felt the home committments interfered more with work. This differing viewpoint is of statistical significance as mentioned above. A third of the husbands tended to deal with related problems on their own, which exacerbated stress. Shouting, getting upset and crying were common methods used by wives to cope with stress, which had a negative effect on the couple's relationship, and therefore on the family. The marital relationship was an area of expressed concern and a stressor in $25 \%$ of the cases.

\section{Limited family and couple time}

Limited family and couple time was a concern of two-thirds of both husbands and wives. Most respondents said they would like to increase family and couple time spent having fun together. Several wives commented that they felt like single parents and resented this. It was this aspect that seemed to evoke the greatest hostility about being self-employed from wives. The finding by Beutell \& Greenhaus (1993: 47) may again be cited to highlight the dissatisfaction experienced by the wives in this study when attempting to 'be supermother' and undertaking all roles with time management, this not being a 'successful strategy'.

\section{Conclusions and recommendations}

Self-employment is a viable and sometimes necessary option to economic productivity. Results of the study reflect real awareness of the constraints imposed by job reservation 
policies, the price of democratizing the South African economy and the need for affirmation and reward which is not always realizable during times of economic restraint.

Self-employment within South Africa's changing socioeconomic scenario needs to be viewed from a multiplicity of angles. A holistic view of the systemic relationships that influence and are influenced by the business needs to be adopted to promote understanding and appropriate planning. Joint commitment of the spouses in the business venture is necessary so that partners could be relied on to share successes and failures with each other, resulting in joint responsibility and effective problem solving. Thus if the numerous micro systems which make up the larger macro system aspire for productivity jointly, then the likely effect on the macro system is inevitably favourable in economic and social terms.

In order that the benefits of self-employment positively impact on the marriage, and not cost the couple their marriage, counselling and preventive education is necessary. It was evident from the study that the couple that opts for self-employment needs to function as a team that communicates clearly and makes informed decisions jointly.

Constructive conflict management is an important skill that such a team has to acquire to ensure that all eventualities are adequately managed. This will not occur of its own accord. Firstly the costs to a marriage without adequate preparation for self-employment must be recognized. Then, deliberate efforts need to be made to provide an infrastructure for such preparation. Lobbying for the creation of this infrastructure is necessary or else the preparation will be neglected to accommodate other concerns which may seem to have a more direct bearing on productivity and benefits. A suggestion is for subsidising sponsors to employ counsellors to undertake this preparation and counselling, since sponsors often have a stake in the outcome of the business. Thus alongside commitment to the business there should be commitment to the marriage as both influence each other systemically.

Constant appraisal of both the business and the marriage would facilitate management of parenting roles and allow for provision of at least some couple and family time. Appraisal could be achieved during weekly family meetings that include elements of praise and constructive problem solving. Such meetings would culminate in teamwork and would prevent either spouse from feeling misunderstood, neglected or having to manage all responsibilities as a 'superbeing'. In addition, meetings could focus on a variety of relevant issues affecting the household such as budgeting. In the latter example, both partners could be encouraged to reach consensus on defining necessities and luxuries.

Couples embarking on self-employment could receive preventive education to teach constructive methods of coping with stress and on the importance of stress release. These need to be individualized to ensure that they are implemented within the peculiar time constraints experienced by most selfemployed persons.

Clearly, married couples in self-employment face many problems which impact on both their marriages and the business. The reciprocal relationship between marriage and the business needs to be accepted and further investigated. A helpful starting point would be to undertake research using a larger sample and with couples who have not been for marital counselling.

Finally, the authors urge that there be deliberate focus on interdisciplinary collaboration. This is in accord with the systems perspective adopted in the study that sub systemic relationships be comprehensively explored with a view to serving the individual, the business and the disciplines with which they are linked.

\section{References}

Bailey, K. D. 1978. Methods of social research. 6th edition. New York: The Free Press

Baruch, G.K. \&Barnett, R.C. 1986. 'Consequences of fathers' participation in family work: parents' role strain and well-being', Journal of Personality and Social Psychology, Vol. 51. No. 5: 983-992.

Beutell, N.J. \& Greenhaus, J.H. 1983. 'Integration of home and nonhome roles: women's conflict and coping behavior', Journal of Applied Psychology, Vol. 68, No. 1: 43-48.

Cooper, C.L.\& Davidson, M. 1987. 'Sources of stress at work and their relation to stressors in non-working environments'. In Kalimo R., El-Batawi, M.A. \& Cooper, C.L. (Eds.). Psychosocial factors at work and their relation to health. Geneva: World Health Organization.

Deshpande, R. 1983. 'Paradigms lost: on theory and method in research in marketing', Journal of Marketing, Vol. 47: 101-110.

Duxbury, L.E. \& Higgins, C.A. 1991. 'Gender differences in workfamily conflict', Journal of Applied Psychology, Vol. 76, No. 1: 60-74.

Moon, S.M., Dillon, D.R. \& Sprenkle, D.H. 1990. 'Family therapy and qualitative research', Journal of Marital and Family Therapy, Vol. 16, No. 4: 357-373.

Mouton, J. 1989. 'What would an adequate philosophy of social work research look like?', The Social Work Practitioner/Researcher, September: 15-21.

Olm, K.W. \& Eddy, G.G. 1985. Entrepreneurship and venture management. Columbus, Ohio: Charles E. Merrill Publishing Company.

Pottick, K.J. 1989. 'The Work role as a major life role', Social Casework, Vol. 70, No. 8: 488-493.

Small Business Development Corporation. 1993. Annual report.

Small Business Week, 1993. 'Small and medium enterprises: a definition and the link with big business', 4-11 September.

Snyman, I. 1991. 'Entrepreneurship: a few facts and figures', South African Journal of Entrepreneurship and Small Business, December: $1-13$.

Taylor, V. 1994. National social welfare and development plan. University of the Western Cape, Bellville: SADEP.

Tomm, K. 1984. 'One perspective on the Milan systemic approach: Part 1 Overview of development, theory and practice', Journal of Marital and Family Therapy, Vol. 10, No. 2: 113-125.

Tripodi, T. 1983. Evaluative research for social workers. New Jersey: Prentice Hall Inc.

Tripodi, T., Fellin, P. \& Meyer, H.J. 1983. The assessment of social research, 2nd edition. Itasco, Illinois: F. E. Peacock Publishers Inc. 